\title{
Faktor yang Berhubungan dengan Konsumsi Energi lbu Menyusui Di Kecamatan Cipayung, Kota Depok, Indonesia
}

\section{Factors Associated with Energy Consumption of Lactating Mothers in Cipayung District, Depok City, Indonesia}

Netti Yaneli ${ }^{*}{ }_{1}$, Sandra Fikawati ${ }^{2}$, Ahmad Syafiq ${ }^{3}$, dan Syilga Cahya Gemily ${ }^{4}$

\begin{abstract}
ABSTRAK
Latar Belakang: Untuk mendukung kebutuhan gizi yang tinggi saat menyusui, ibu menyusui membutuhkan lebih banyak energi dibandingkan ibu hamil. Namun, berbagai studi melaporkan bahwa konsumsi energi ibu menyusui justru lebih rendah dibandingkan ibu hamil.

Tujuan: Mengetahui faktor yang berhubungan dengan konsumsi energi ibu menyusui di Kecamatan Cipayung Kota Depok Indonesia.

Metode: Penelitian ini merupakan penelitian kuantitatif dengan desain cross sectional yang menganalisis data sekunder dari penelitian eksperimental semu dengan pendekatan kohort prospektif di Kota Depok. Total sampel berjumlah 169 responden. Analisis data pada penelitian ini menggunakan uji chi-square dan uji regresi logistik ganda.

Hasil: Konsumsi energi ibu saat hamil dan usia ibu merupakan faktor yang berhubungan dengan konsumsi energi ibu saat menyusui setelah dikontrol dengan paritas dan status gizi ibu. Ibu yang mengonsumsi energi dalam jumlah kurang saat hamil berisiko 3,5 kali lebih besar untuk mengonsumsi energi dalam jumlah kurang saat menyusui. Ibu muda ( 27 tahun) berisiko 2,8 kali lebih besar untuk mengonsumsi energi dalam jumlah kurang saat menyusui.

Kesimpulan: Konsumsi energi ibu hamil sangat penting diperhatikan karena diperlukan untuk pertumbuhan dan perkembangan janin, sebagai cadangan lemak yang akan digunakan saat menyusui, juga untuk menjamin agar ibu mengonsumsi energi dalam jumlah cukup saat menyusui.
\end{abstract}

Kata kunci: Konsumsi Energi, Ibu Menyusui, Ibu Hamil

\section{ABSTRACT}

Background: To support the high nutritional needs during breastfeeding, lactating mothers need more energy than pregnant women. However, various studies report that the energy consumption of lactating mothers is actually lower than pregnant women.

Objectives: Determine the factors associated with energy consumption of lactating mothers in Cipayung Subdistrict, Depok City, Indonesia.

Methods: This study was a quantitative research used secondary data from quasi-experimental research using a prospective cohort approach in Depok City. The total sample was 169 respondents. Data analysis used the chi-square test and multiple logistic regression tests.

Results: Maternal energy consumption during pregnancy was the dominant factor associated with maternal energy consumption while breastfeeding after being controlled for parity and maternal age. Mothers who consume less energy during pregnancy were 3.5 times more likely to consume less energy while breastfeeding. Young mothers (<27 years) were 2.8 times more likely to consume less energy while breastfeeding.

Conclusions: Energy consumption of pregnant women is very important because it is needed for the growth and development of the fetus, as a reserve of fat to be used while breastfeeding, also to ensure that mothers consume adequate amounts of energy when breastfeeding

Keywords: Energy, Lactating Mothers, Pregnant Mothers

*Korespondensi:

netti15natuna@gmail.com

Netti Yaneli

Fakultas Kesehatan Masyarakat, Universitas Indonesia 


\section{PENDAHULUAN}

Stunting adalah kondisi dimana balita memiliki panjang atau tinggi badan $<-2$ SD jika dibandingkan dengan umur. ${ }^{1}$ Dampak stunting pada kesehatan bukan hanya terjadinya gagal tumbuh pada masa anak-anak, tetapi juga hambatan perkembangan kognitif dan motorik, serta gangguan metabolik saat dewasa. 2,3 Stunting merupakan kondisi malnutrisi pada anak dengan prevalensi yang tinggi di Indonesia. Berdasarkan data Riskesdas tahun 2018 diketahui bahwa prevalensi stunting pada balita sebesar $30,8 \%$. Prevalensi stunting pada anak berusia di bawah dua tahun (baduta) tidak jauh berbeda yaitu 29,9\%. ${ }^{4}$ WHO menyebutkan bahwa stunting dimulai pada 1000 hari pertama kehidupan (1000 HPK) dan terkait dengan banyak faktor, termasuk status lingkungan, sosial ekonomi, infeksi, penyakit menular, defisiensi mikronutrien, konsumsi makanan, dan status gizi ibu. ${ }^{5}$

Salah satu faktor yang berhubungan dengan stunting adalah kurangnya gizi ibu pada masa hamil dan menyusui.6,7 Pada masa menyusui, kandungan energi, protein, dan zat gizi dalam ASI berasal dari makanan dan persediaan tubuh ibu. ${ }^{8}$ Jika ibu tidak mendapatkan asupan gizi yang cukup selama hamil dan menyusui maka kandungan gizi yang terdapat pada ASI juga terpengaruh yang berakibat pada tidak tercukupinya zat gizi bayi sehingga terjadi kekurangan gizi kronis yang menyebabkan stunting. ${ }^{9}$

Pada masa menyusui, ibu membutuhkan lebih banyak energi dibandingkan saat hamil karena ibu harus memproduksi ASI. ${ }^{8}$ Berdasarkan Angka Kecukupan Gizi (AKG) di Indonesia, ibu menyusui membutuhkan energi sebesar 2650 kkal/hari. ${ }^{10}$ Namun berbagai studi menunjukkan bahwa konsumsi energi ibu selama menyusui lebih rendah jika dibandingkan dengan asupan energi ibu saat hamil 11,12,13 dan konsumsi energi ibu menyusui lebih rendah dari yang disarankan. ${ }^{14-16}$ Penelitian juga menunjukkan bahwa selain konsumsi energi ibu menyusui rendah, konsumsi energi ibu menyusui terus berkurang sejak bulan pertama hingga bulan ke enam menyusui. ${ }^{17,18}$

Konsumsi energi ibu menyusui dapat dipengaruhi oleh beberapa faktor seperti konsumsi ibu saat hamil, kurangnya pengetahuan dan sikap mengenai tingginya kebutuhan gizi saat laktasi, kesibukan ibu mengurus bayi, berkurangnya konsumsi susu dan suplemen, adanya pantangan makan, serta kurangnya informasi dari tenaga kesehatan mengenai jumlah kebutuhan gizi ibu laktasi. 19,20 Di Indonesia, studi melaporkan bahwa konsumsi energi ibu menyusui rendah dan tidak mencapai angka yang direkomendasikan. ${ }^{18,21-24}$ Kecamatan Cipayung di Kota Depok merupakan wilayah yang memiliki cakupan ASI eksklusif rendah yakni sebesar $56,54 \% .{ }^{25}$. Salah satu faktor penyebab rendahnya cakupan ASI Eksklusif ini adalah karena kurangnya konsumsi energi ibu selama menyusui. ${ }^{26}$ Tujuan dari penelitian ini adalah untuk mengetahui faktor yang berhubungan dengan rendahnya konsumsi energi ibu menyusui di Kecamatan Cipayung Kota Depok Tahun 2016.
METODE

Penelitian kuantitatif dengan desain cross sectional ini menganalisis data sekunder dari penelitian eksperimental semu dengan pendekatan kohort prospektif yang berjudul "Intervensi Peningkatan ASI dan MPASI dalam rangka Penerapan Program 1000 Hari Pertama Kehidupan melalui Penelitian dan Pengabdian Masyarakat" yang berlokasi di Kecamatan Cipayung Kota Depok. Penelitian ini menganalisis faktor-faktor berhubungan dengan konsumsi energi ibu menyusui. Independen variabel pada studi ini adalah usia ibu, paritas $i b u$, pengetahuan ibu tentang ASI, konsumsi energi ibu saat hamil, status gizi ibu postpartum, tingkat pendidikan ibu, dan status bekerja ibu. Status gizi ibu merupakan IMT postpartum yaitu hasil BB $(\mathrm{kg})$ ibu dibagi dengan kuadrat tinggi badan $\left(\mathrm{m}^{2}\right)$ ibu yang diukur pada saat 6-7 hari setelah melahirkan. Pengukuran konsumsi energi ibu dilakukan dengan menggunakan metode 24-hour recall. Konsumsi energi ibu saat hamil dinilai dari rata-rata jumlah energi yang dikonsumsi ibu dalam satu hari yang diukur saat trimester ke-3 masa kehamilan. Konsumsi energi ibu saat laktasi, sebagai variabel dependen, didefinisikan sebagai jumlah rata-rata energi yang dikonsumsi oleh ibu pada 24 jam terakhir sejak bulan ke1 (6-7 hari setelah persalinan) sampai bulan ke-6 postpartum dalam $\mathrm{kkal} / \mathrm{hari}$ yang diukur setiap bulan. Konsumsi energi ibu dikategorikan menjadi dua kategori, yaitu kurang bila konsumsi energi ibu $<80 \%$ AKG dan cukup bila $\geq 80 \%$ AKG. Penentuan AKG diambil dari Angka Kecukupan Energi (AKE) kelompok usia 19-29 tahun dengan penambahan kebutuhan 180 kkal untuk ibu hamil dan 400 kkal untuk ibu menyusui. ${ }^{27}$

Sampel pada penelitian ini adalah semua responden pada penelitian primer sebanyak 169 responden. Kriteria inklusi sampel pada penelitian ini adalah ibu hamil yang bersedia untuk dipantau proses pemberian ASI, menjalani pengukuran konsumsi energi saat hamil dan laktasi, serta pengukuran status gizi ibu dan bayi selama 6 bulan. Sedangkan kriteria eksklusi sampel pada penelitian ini adalah ibu dengan penyakit kronik seperti kanker, dan HIV/AIDS serta ibu yang alergi dengan protein susu. Analisis data menggunakan uji chisquare untuk mengetahui hubungan antara variabel bebas dengan terikat. Hasil uji dikatakan signifikan jika $p$ value $\leq 0,05$. Penelitian ini telah mendapat persetujuan etik dari Komisi Penelitian dan Etika Penelitian Fakultas Kesehatan Masyarakat Universitas Indonesia (No. 313/UN2.F10/PPM.00.02/2016).

\section{HASIL DAN PEMBAHASAN}

Pada penelitian ini diperoleh hasil bahwa konsumsi energi ibu saat hamil dan menyusui lebih rendah dibandingkan dengan angka kecukupan gizi yang dianjurkan. Pada saat hamil rata-rata konsumsi energi ibu lebih rendah $123 \mathrm{kkal} / \mathrm{hari}$ dibandingkan angka yang dianjurkan (2550 kkal/hari), sedangkan pada masa menyusui rata-rata konsumsi energi lebih rendah 377 kkal/hari dari angka yang dianjurkan (2650 kkal/hari) (Gambar 1). Hasil studi ini didukung oleh penelitian lainnya yang menunjukkan bahwa konsumsi energi ibu pada masa hamil kurang dan di bawah angka kecukupan 
yang direkomendasikan. ${ }^{28-30}$ Konsumsi energi ibu yang rendah saat hamil dapat berdampak pada pertumbuhan dan perkembangan bayi karena energi ekstra selama kehamilan dibutuhkan untuk pertumbuhan janin, serta pertumbuhan jaringan ibu seperti uterus dan plasenta. ${ }^{31,32}$

Rendahnya konsumsi energi ibu saat hamil juga akan berdampak pada berkurangnya cadangan lemak yang ada pada tubuh ibu yang dibutuhkan untuk perkembangan jaringan payudara atau untuk persiapan fisiologis untuk menyusui. 33 Cadangan lemak juga digunakan untuk memenuhi kebutuhan energi ibu untuk menghasilkan persediaan ASI yang cukup selama tiga bulan pertama masa menyusui. ${ }^{20}$

Berdasarkan hasil penelitian ini diketahui bahwa penting untuk memperhatikan asupan ibu saat hamil karena cadangan zat gizi ibu saat hamil akan digunakan pada saat menyusui. ${ }^{34}$ Energi yang dibutuhkan untuk memproduksi 1 liter ASI diperkirakan sekitar 700 kkal, dan ASI yang dikeluarkan dalam 4 bulan laktasi kirakira setara dengan total energi saat hamil. ${ }^{35}$ Jika seorang ibu cukup gizi selama kehamilan, dia akan memiliki cadangan gizi yang dapat digunakan untuk mengimbangi kebutuhan saat menyusui. ${ }^{36}$ Sebaliknya jika ibu yang tidak mengonsumsi energi ekstra selama kehamilan maka cadangan yang ada pada tubuh ibu akan digunakan untuk memproduksi ASI, dan jika cadangan gizi di tubuh ibu semakin habis akan mengakibatkan ibu menjadi kekurangan zat gizi yang kemudian berdampak pada produksi ASI. ${ }^{33}$

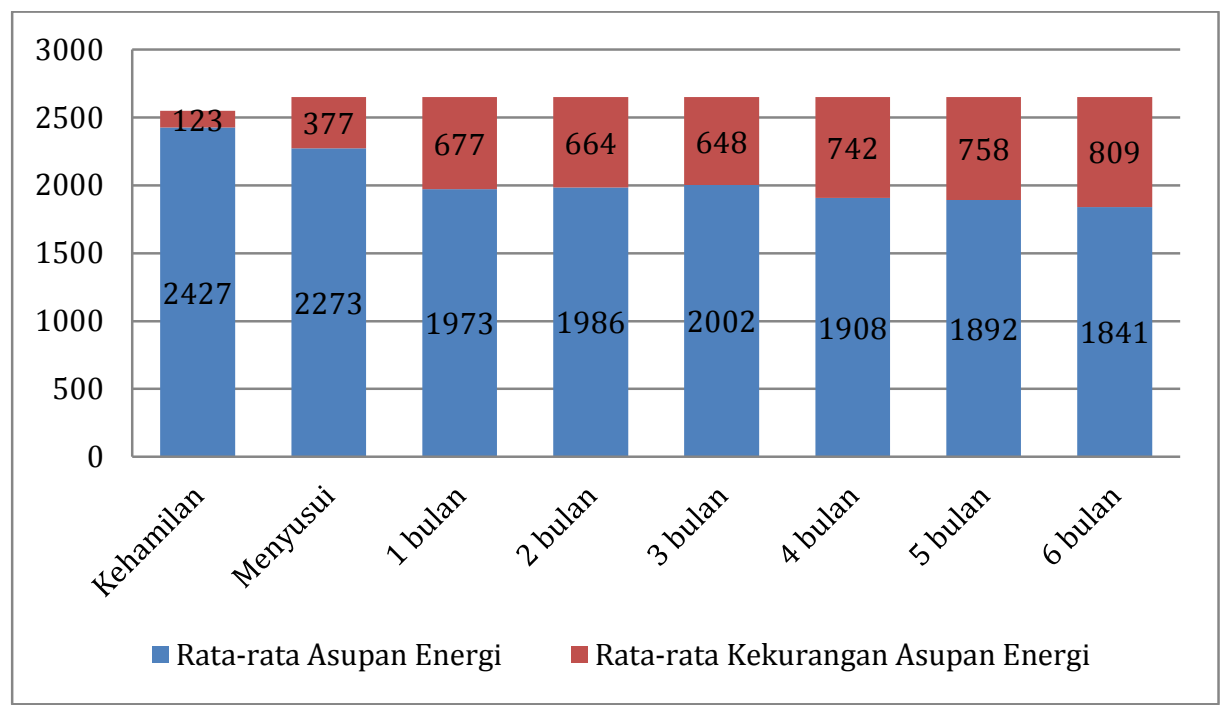

Gambar 1. Perbandingan Rata-rata Konsumsi Energi untuk Ibu Hamil dan Menyusui di Kecamatan Cipayung Kota Depok Tahun 2016

Selanjutnya, penelitian ini juga menemukan bahwa energi ibu menyusui lebih rendah dari yang direkomendasikan. Ibu menyusui hanya mengonsumsi energi sebanyak $2273 \mathrm{kkal} /$ hari. Sejalan dengan penelitian yang dilakukan di Jepang terhadap 129 ibu menyusui yang menunjukkan bahwa ibu menyusui hanya mengonsumsi energi sebesar $1878 \mathrm{kkal} / \mathrm{hari}$ dari angka yang dianjurkan yaitu $2350 \mathrm{kkal} /$ hari. ${ }^{14}$ Beberapa penelitian lain juga melaporkan rendahnya konsumsi energi ibu menyusui dari angka yang direkomendasikan. 17,19,37,38 Ibu menyusui membutuhkan banyak energi dan zat gizi lainnya untuk mempertahankan produksi ASI dalam jumlah dan kualitas yang memadai. Rendahnya konsumsi energi dan zat gizi ibu selama periode menyusui dapat berisiko menipisnya persediaan zat gizi dan kesehatan ibu, serta dapat membahayakan gizi dan kesehatan anak yang sedang tumbuh. Rendahnya konsumsi energi ibu menyusui juga akan berpengaruh pada peluang ibu menyusui ekslusif hingga 6 bulan. Studi menemukan bahwa ibu dengan konsumsi energi laktasi yang rendah memiliki peluang lebih besar untuk tidak dapat menyusui sampai dengan 6 bulan. ${ }^{11,17,18}$
Dalam hal rendahnya konsumsi energi ibu menyusui, penelitian lain juga menunjukkan bahwa jumlah asupan energi berhubungan signifikan dengan Persepsi Ketidakcukupan ASI (PKA). Ibu yang asupan energinya kurang, berisiko 3,7 kali lebih besar mengalami PKA dibandingkan dengan ibu yang asupannya cukup. ${ }^{24}$ PKA adalah keadaan seorang ibu yang menganggap dirinya tidak lagi memiliki ketersediaan ASI yang cukup. ${ }^{39}$ Hasil penelitian juga menunjukkan bahwa konsumsi energi ibu saat menyusui lebih rendah dibandingkan dengan saat hamil. Pada masa kehamilan, ibu mengonsumsi energi rata-rata sebesar 2427 kkal/hari, sedangkan pada masa menyusui konsumsi energi ibu turun menjadi rata-rata sebesar 2273 kkal/hari. Jika dilihat berdasarkan bulan menyusuinya diperoleh bahwa konsumsi energi ibu menyusui cenderung fluktuatif dari bulan pertama hingga ke enam. Dari bulan pertama hingga ketiga, konsumsi energi ibu mengalami peningkatan, akan tetapi dari bulan ke empat hingga ke enam mengalami penurunan bahkan konsumsinya sangat rendah yaitu hanya $1841 \mathrm{kkal} / \mathrm{hari}$.

Penelitian yang dilakukan di Brazil menunjukkan bahwa konsumsi energi ibu menyusui lebih 
rendah dibandingkan saat hamil. Sebelum masa menyusui, ibu mengonsumsi energi sebesar 1964 kkal/hari dan saat menyusui sebesar 1804 kkal/hari. ${ }^{12}$ Penelitian lain juga melaporkan rendahnya konsumsi energi ibu saat menyusui dibandingkan dengan saat hamil. ${ }^{11,13,40}$ Konsumsi energi ibu saat menyusui yang lebih rendah daripada saat hamil dapat terjadi karena ibu hamil tidak mempunyai waktu untuk memperhatikan pola makan yang baik untuk dirinya. ${ }^{16,20}$ Periode postpartum adalah masa di mana ibu menyusui menyesuaikan diri dengan rutinitas baru seperti merawat anak sehingga ibu tidak terlalu memperhatikan diri sendiri termasuk asupan gizi. ${ }^{16}$ Selain itu, ibu menyusui juga beranggapan bahwa kebutuhan zat gizi saat menyusui tidak sebanyak kebutuhan saat hamil. Ibu menyusui menganggap ketika anak sudah lahir maka ibu tidak perlu lagi mengonsumsi makanan lebih banyak. ${ }^{20}$ Padahal pada saat menyusui, energi ekstra dibutuhkan ibu untuk memproduksi ASI. Saat menyusui, ibu juga tidak mengubah pola makannya atau menambah asupan makan saat menyusui. Makanan yang dikonsumsi ibu saat menyusui cenderung sama dengan saat hamil. ${ }^{37}$

Tabel 1. Hubungan Karakteristik dengan Konsumsi Energi Ibu Menyusui

\begin{tabular}{|c|c|c|c|c|c|c|c|c|}
\hline \multirow{3}{*}{ Variabel } & \multicolumn{4}{|c|}{ Konsumsi Energi Ibu Menyusui } & \multirow{2}{*}{\multicolumn{2}{|c|}{ Total }} & \multirow{3}{*}{$\begin{array}{c}\text { OR } \\
(95 \% \mathrm{Cl})\end{array}$} & \multirow{3}{*}{$p$ value } \\
\hline & \multicolumn{2}{|c|}{$<80 \%$ AKG } & \multicolumn{2}{|c|}{$\geq 80 \%$ AKG } & & & & \\
\hline & $\mathbf{n}$ & $\%$ & $\mathbf{n}$ & $\%$ & $\mathbf{N}$ & $\%$ & & \\
\hline \multicolumn{9}{|l|}{ Usia Ibu } \\
\hline$<27$ tahun & 25 & 45,5 & 30 & 54,5 & 55 & 100 & 1,5 & \multirow{2}{*}{0,259} \\
\hline$\geq 27$ tahun & 40 & 35,1 & 74 & 64,9 & 144 & 100 & $(0,800-2,969)$ & \\
\hline \multicolumn{9}{|l|}{ Paritas } \\
\hline Multipara & 53 & 39,0 & 83 & 61,0 & 136 & 100 & 1,1 & \multirow{2}{*}{0,939} \\
\hline Primipara & 12 & 36,4 & 21 & 63,6 & 33 & 100 & $(0,508-2,459)$ & \\
\hline \multicolumn{9}{|c|}{ Pengetahuan Ibu tentang ASI } \\
\hline Kurang & 35 & 42,7 & 47 & 57,3 & 82 & 100 & 1,4 & \multirow{2}{*}{0,349} \\
\hline Baik & 30 & 34,5 & 57 & 65,5 & 87 & 100 & $(0,760-2,636)$ & \\
\hline \multicolumn{9}{|c|}{ Konsumsi Ibu saat Hamil } \\
\hline Kurang & 36 & 55,4 & 29 & 44,6 & 65 & 100 & 3,2 & \multirow[t]{2}{*}{$0,001 *$} \\
\hline Cukup & 29 & 27,9 & 75 & 72,1 & 104 & 100 & $(1,676-6,151)$ & \\
\hline \multicolumn{9}{|c|}{ Status Gizi Ibu Postpartum } \\
\hline Berisiko & 36 & 42,9 & 48 & 57,1 & 84 & 100 & 1,5 & \multirow{2}{*}{0,313} \\
\hline Normal & 29 & 34,1 & 56 & 65,9 & 85 & 100 & $(0,777-2,700)$ & \\
\hline \multicolumn{9}{|c|}{ Tingkat Pendidikan Ibu } \\
\hline Rendah & 30 & 40,5 & 44 & 55,5 & 74 & 100 & 1,2 & \multirow{2}{*}{0,741} \\
\hline Tinggi & 35 & 36,8 & 60 & 63,2 & 95 & 100 & $(0,626-2,181)$ & \\
\hline \multicolumn{9}{|c|}{ Status Bekerja Ibu } \\
\hline Bekerja & 9 & 40,9 & 13 & 59,1 & 22 & 100 & 1,1 & \multirow{2}{*}{0,986} \\
\hline Tidak bekerja & 56 & 38,1 & 91 & 61,9 & 147 & 100 & $(0,452-2,803)$ & \\
\hline
\end{tabular}


Hasil analisis bivariat (Tabel 1) menunjukkan bahwa ada hubungan signifikan antara konsumsi energi ibu selama kehamilan dan konsumsi energi ibu menyusui dengan $O R=3,2$ yang artinya ibu yang pada saat hamil mengonsumsi energi kurang memiliki risiko tiga kali lebih besar untuk mengonsumsi energi yang juga kurang pada saat menyusui. Usia ibu lebih dari 27 tahun, multi paritas, pengetahuan ibu tentang ASI yang kurang, status ibu postpartum berisiko, tingkat pendidikan ibu rendah, dan ibu yang bekerja juga memiliki risiko untuk mengonsumsi energi kurang saat menyusui, walaupun pada penelitian ini tidak signifikan secara statistik.

Selanjutnya, analisis multivariat dilakukan dengan memasukkan variabel bebas yaitu usia ibu, paritas ibu, pengetahuan ibu tentang ASI, konsumsi ibu saat hamil, status gizi ibu postpartum, tingkat pendidikan ibu dan status bekerja ibu pada model awal. Hasil seleksi bivariat variabel yang menghasilkan $p$ value $<0,25$ adalah usia ibu, konsumsi ibu hamil, dan status gizi ibu postpartum. Variabel paritas, pengetahuan ibu tentang ASI, pendidikan ibu, dan status bekerja tetap dimasukan dalam analisis multivariat oleh karena secara substansi penting dan berhubungan dengan konsumsi energi ibu menyusui. Hastono (2018) menyebutkan bahwa hasil uji bivariat dengan nilai $p>0,25$ tetap dapat diikutkan dalam analisis multivariat bila variabel tersebut secara substansi penting ${ }^{41}$. Hasil akhir analisis multivariat (Tabel 2) menunjukkan bahwa konsumsi energi ibu hamil dan usia ibu merupakan faktor yang berhubungan dengan konsumsi energi ibu menyusui setelah dikontrol dengan paritas dan status gizi ibu. Ibu dengan konsumsi energi yang rendah saat hamil berisiko 3,5 kali untuk mengonsumsi energi yang juga rendah pada masa menyusui. Ibu muda ( $<27$ tahun) berisiko 2,8 kali untuk mengonsumsi energi yang juga pada masa menyusui.

Tabel 2. Faktor yang Berhubungan dengan Konsumsi Energi Ibu Menyusui

\begin{tabular}{lccc}
\hline \multicolumn{1}{c}{ Variabel } & P Value & OR & Cl 95\% \\
\hline Konsumsi energi ibu hamil & $0,000^{*}$ & $3,551^{* *}$ & $1,810-6,968$ \\
Paritas & 0,117 & 2,398 & $0,804-7,152$ \\
Usia Ibu & $0,026^{*}$ & 2,845 & $1,132-7,149$ \\
Status gizi & 0,147 & 1,648 & $0,839-3,240$ \\
\hline
\end{tabular}

*) p value $\leq 0,05$

${ }^{* *}$ ) Nilai OR paling tinggi

Hasil ini sejalan dengan penelitian yang menunjukkan bahwa konsumsi energi ibu hamil berpengaruh terhadap konsumsi energi ibu menyusui. $18,19,42$ lbu yang sudah terbiasa mengonsumsi makanan dalam jumlah yang banyak saat hamil cenderung akan terbiasa juga untuk mengonsumsi makanan lebih banyak saat menyusui. Bila saat hamil konsumsi ibu rendah maka pada saat menyusui konsumsinya akan lebih rendah lagi. Penelitian juga menyebutkan bahwa kebiasaan makan saat hamil dapat mempengaruhi asupan makan ibu menyusui. ${ }^{35}$ Oleh karena itu penting untuk memperhatikan kebiasaan makan saat hamil terutama kebiasaan konsumsi energi untuk menjaga agar ibu juga mengonsumsi energi dalam jumlah yang cukup saat menyusui.

Pada penelitian ini ibu muda $(<27$ tahun) mengonsumsi energi saat menyusui lebih rendah daripada ibu yang cukup umur ( $\geq 27$ tahun). Hasil ini berbeda dengan hasil penelitian Tavares dan Syafiq yang menyatakan bahwa semakin tinggi usia ibu maka akan semakin rendah konsumsi energi ibu menyusui 16,18 karena ibu dengan usia yang lebih tua memiliki motivasi untuk membatasi konsumsi energi yang disebabkan oleh melambatnya metabolisme sehingga lemak menumpuk lebih mudah. ${ }^{18}$ Pada penelitian ini, konsumsi energi pada ibu muda yang lebih rendah dapat terjadi karena ibu sibuk bekerja sehingga tidak bisa memperhatikan pola makan yang seimbang untuk mencukupi kebutuhan energi. Selain itu, pada ibu muda yang baru pertama kali mempunyai anak akan cenderung belum terbiasa dengan rutinitas baru setelah melahirkan seperti mengurus anak sehingga ibu tidak terlalu memperhatikan diri sendiri termasuk asupan gizi.

\section{KESIMPULAN}

Faktor yang berhubungan dengan konsumsi energi ibu saat menyusui adalah konsumsi energi ibu ketika hamil dan usia ibu. Ibu yang mengonsumsi energi yang kurang selama hamil akan mempunyai risiko 3,5 kali lebih besar untuk mengonsumsi energi yang juga kurang selama menyusui, serta ibu muda ( $<27$ tahun) berisiko 2,8 kali untuk mengonsumsi energi yang kurang pada masa menyusui. Ditemukan juga bahwa konsumsi energi ibu saat menyusui lebih rendah dibandingkan saat hamil dimana rata-rata konsumsi energi keduanya di bawah Angka Kecukupan Gizi yang dianjurkan. Terjadi penurunan yang cukup signifikan pada konsumsi energi dari 1 bulan postpartum hingga 6 bulan postpartum. Konsumsi energi ibu hamil sangat penting diperhatikan karena selain diperlukan untuk pertumbuhan dan perkembangan janin, sebagai cadangan lemak yang akan digunakan saat menyusui, juga untuk menjaga agar ibu mengonsumsi energi dalam jumlah cukup saat menyusui.

\section{ACKNOWLEDGEMENT}

Ucapan terima kasih disampaikan kepada Kementerian Kesehatan Republik Indonesia atas dana penelitian yang diberikan melalui Paket Intervensi Masalah Gizi dan Penerapan 1000 Hari Pertama Kehidupan (HPK) di Wilayah Barat nomor: km.04.01 /bv .21229312016 . 


\section{REFERENSI}

1. World Health Organization. Nutrition Landscape Information System (NLIS) Country Profile Indicators. (2010).

2. Adair, L. S. \& Guilkey, D. K. Age-Specific Determinants of Stunting in Filipino Children 1 , 2 , 3. 314-320 (1997).

3. Prendergast, A. J., Humphrey, J. H., Prendergast, A. J. \& Humphrey, J. H. Paediatrics and International Child Health The stunting syndrome in developing countries The stunting syndrome in developing countries. 9047, (2014).

4. Badan Penelitian dan Pengembangan Kesehatan. Hasil Utama RISKESDAS 2018. (Badan Penelitian dan Pengembangan Kesehatan, Kementerian Kesehatan RI, 2018).

5. WHO. Child Stunting Data Visualizations Dashboard. (2018).

6. Beal, T., Tumilowicz, A., Sutrisna, A., Izwardy, D. \& Neufeld, L. M. A review of child stunting determinants in Indonesia. Matern. Child Nutr. 14, 1-10 (2018).

7. Raiten, D. J. \& Bremer, A. A. Exploring the nutritional ecology of stunting: New approaches to an old problem. Nutrients 12, (2020).

8. Segura, S. A., Ansótegui, J. A. \& Marta DíazGómez, N. The importance of maternal nutrition during breastfeeding: Do breastfeeding mothers need nutritional supplements? An. Pediatr. 84, 347.e1-347.e7 (2016).

9. Chirande, L. et al. Determinants of stunting and severe stunting among under-fives in Tanzania : evidence from the 2010 cross-sectional household survey. 1-13 (2015) doi:10.1186/s12887-015-0482-9.

10. Menteri Kesehatan RI. Peraturan Menteri Kesehatan Republik Indonesia Nomor 28 Tahun 2019 Tentang Angka Kecukupan Gizi yang Dianjurkan untuk Masyarakat Indonesia. (Kementerian Kesehatan RI, 2019).

11. Fikawati, S., Syafiq, A. \& Mardatillah. Maternal calorie intake is a significant factor associated with 6 months of exclusive breastfeeding among lactating mothers in Depok City, Indonesia. Malays. J. Nutr. 23, 31-41 (2017).

12. Dos Santos, Q., Sichieri, R., Marchioni, D. M. L. \& Verly Junior, E. Brazilian pregnant and lactating women do not change their food intake to meet nutritional goals. BMC Pregnancy Childbirth 14, 1-7 (2014)

13. Rao, K. M., Balakrishna, N., Arlappa, N., Laxmaiah, A. \& Brahmam, G. N. V. Diet and Nutritional Status of Women in India. J. Hum. Ecol. 29, 165-170 (2010).

14. Minato, T. et al. Maternal undernutrition and breast milk macronutrient content are not associated with weight in breastfed infants at 1 and 3 months after delivery. Int. J. Environ. Res. Public Health 16, (2019).

15. Pratt, N. S., Durham, H. A. \& Sherry, C. L. Nutrient
Intakes from Food of Lactating Women Do Not Meet Many Dietary Recommendations Important for Infant Development and Maternal Health. Food Nutr. Sci. 05, 1644-1651 (2014).

16. Tavares, M. P., Devincenzi, M. U., Sachs, A. \& De Vilhena Abrão, A. C. F. Nutritional status and diet quality of nursing mothers on exclusive breastfeeding. ACTA Paul. Enferm. 26, 294-298 (2013).

17. Sihite, D. S., Fikawati, S. \& Syafiq, A. Maternal Energy Intake at the Sixth Month as Dominant Factor of Exclusive Breastfeeding Success. Natl. Public Heal. J. 12, 87-92 (2017).

18. Syafiq, A., Fikawati, S. \& Widiastuti, R. Energy Consumption during Lactation and Duration of Breastfeeding At Puskesmas Margajaya Bekasi City in 2014. Makara J. Heal. Res 19, (2015)

19. Fikawati, S., Syafiq, A. \& Suryani, E. Lactating Mothers Energy Consumption in Beji Subdistricts Depok City Indonesia in 2016. Proc. ISER 88 Int. Conf. (2017).

20. Fikawati, S., Syafiq, A., Purbaningrum, R. P. \& Karima, K. Energy Consumption of Lactating Mothers: Current Situation and Problems. Makara J. Heal. Res 18, 58-64 (2014).

21. Fikawati, S., Syafiq, A. \& Mardatillah. Perbedaan Asupan Susu dengan Kejadian Stunting pada Anak Usia 25-30 Bulan di Jakarta Pusat Tahun 2019. (2019).

22. Rahmawati, W. et al. Gambaran Masalah Gizi pada 1000 HPK di Kota dan Kabupaten Malang, Indonesia. Indones. J. Hum. Nutr. 3, 20-31 (2016).

23. Pangestuti, D. R. Nutritional status of exclusive compared to non exclusive breastfeeding mother. J. Gizi dan Pangan 13, 11-16 (2018).

24. Prabasiwi, A., Fikawati, S. \& Syafiq, A. ASI Eksklusif dan Persepsi Ketidakcukupan ASI Exclusive Breastfeeding and Perception of Insufficient Milk Supply. J. kesmas fkmui 9, (2014).

25. Dinas Kesehatan Kota Depok. Profil Kesehatan Kota Depok Tahun 2018. vol. 187 (2019).

26. Nopiyanti, A. Suplementasi susu pada ibu sebagai faktor dominan lama pemberian ASI eksklusif di wilayah kerja Puskesmas Cipayung, Depok tahun 2017. (2017).

27. Kementerian Kesehatan Republik Indonesia. Peraturan Menteri Kesehatan Republik Indonesia Nomor 28 Tahun 2019 tentang Angka Kecukupan Gizi yang Dianjurkan Untuk Masyarakat Indonesia. (2019).

28. Jones, K. S., Assar, S., Prentice, A. \& Schoenmakers, I. Vitamin D expenditure is not altered in pregnancy and lactation despite changes in Vitamin D metabolite concentrations. Sci. Rep. 6, 1-12 (2016).

29. Neumann, C. G. et al. Low vitamin B12 intake during pregnancy and lactation and low 
breastmilk vitamin B12 content in rural Kenyan women consuming predominantly maize diets. Food Nutr. Bull. 34, 151-159 (2013).

30. Ogechi, U. P. A study of the nutritional status and dietary intake of lactating women in Umuahia, Nigeria. Am. J. Heal. Res. 2, 20-26 (2014).

31. Most, J., Dervis, S., Haman, F., Adamo, K. B. \& Redman, L. M. Energy intake requirements in pregnancy. Nutrients 11, (2019).

32. Mecacci, F., Biagioni, S., Ottanelli, S. \& Mello, G. Nutrition in pregnancy and lactation: how a healthy infant is born. J. Pediatr. neonatal Individ. Med. 4, 1-14 (2015).

33. Kominiarek, M. A. \& Rajan, P. Nutrition Recommendations in Pregnancy and Lactation. Med Clin North Am 100, 1199-1215 (2016).

34. Hoffmann, J. F. et al. Dietary patterns during pregnancy and the association with sociodemographic characteristics among women attending general practices in southern Brazil: the ECCAGe Study. Cad. Saude Publica 29, 970-980 (2013).

35. Hall Moran, V. et al. Nutritional requirements during lactation. Towards European alignment of reference values: The EURRECA network. Matern. Child Nutr. 6, 39-54 (2010).

36. Haileslassie, K., Mulugeta, A. \& Girma, M. Feeding practices, nutritional status and associated factors of lactating women in Samre
Woreda, South Eastern Zone of Tigray, Ethiopia. Nutr. J. 12, 1-11 (2013).

37. Maharani, H., Pangestuti, D. R. \& Pradigdo, S. F. Faktor-faktor yang Berhubungan dengan Status Gizi Ibu Menyusui di Wilayah Kerja Puskesmas Kedungmundu Kota Semarang. J. Kesehat. Masy. 4, 187-196 (2016).

38. Madanijah, S. et al. Nutritional status of lactating women in Bogor district, Indonesia: crosssectional dietary intake in three economic quintiles and comparison with pre-pregnant women. Br. J. Nutr. 116, S67-S74 (2016).

39. Fikawati, S. \& Syafiq, A. Status Gizi Ibu dan Persepsi Ketidakcukupan Air Susu Ibu Maternal Nutritional Status and Breast Milk Insufficiency Perception. J. Kesehat. Masy. Nas. 6, 249-254 (2012).

40. Murrin, C., Shrivastava, A. \& Kelleher, C. C. Maternal macronutrient intake during pregnancy and 5 years postpartum and associations with child weight status aged five. Eur. J. Clin. Nutr. 67, 670-679 (2013).

41. Hastono, S. P. Analisis Data pada Bidang Kesehatan. (PT RajaGrafindo Persada, 2018).

42. Nuradiana, S. Konsumsi Energi Ibu Saat Hamil Sebagai Faktor Dominan Terhadap Konsumsi Energi Ibu Selama Menyusui di Kecamatan Beji, Depok Tahun 2016. (Universitas Indonesia, 2016). 